\title{
Chlamydial Abortion in Algerian Small Ruminants
}

\author{
Salah-Eddine MERDJA ${ }^{1}$, Hamza KHALED ${ }^{1}$, Ali DAHMANI ${ }^{1}$, Abdallah BOUYOUCEF ${ }^{1 *}$ \\ ${ }^{1}$ University of Blida 1, Institute of Veterinary Science, Blida, 09000, Algeria. \\ Corresponding author: abouyoucef57@yahoo.fr
}

Bulletin UASVM Veterinary Medicine 72(1) / 2015,

Print ISSN 1843-5270; Electronic ISSN 1843-5378

DOI:10.15835/buasvmcn-vm: 10283

\begin{abstract}
Chlamydial abortion in small ruminants is a zoonotic disease mainly related to Chlamydia abortus. This bacterium is responsible for abortions and reproductive disorders in sheep and goats. Stillbirth and infertility, leading to important economic losses, are also associated to this pathology.

In Algeria, abortion cases are frequently reported by veterinarians but, except for brucellosis, which is a notified disease in this country, abortive diseases are in general poorly studied. In order to detect the presence of Chlamydia antibodies in small ruminants in the region of Ksar El-Boukhari, 144 blood samples from 17 farms were collected. Sera were examined by indirect ELISA Kit (LSI VET Ruminant Serum Chlamydiosis, France). The test detects antibodies of the two most common Chlamydiaceae spp. affecting sheep and goats, namely Chlamydia abortus and Chlamydia pecorum. The assay was performed and results calculated according to the manufacturer's instructions.

51 animals were positive, representing an observed prevalence rate of $(35 \pm 08) \%$ and 15 herds were seropositive, representing an observed prevalence rate of $(88 \pm 15) \%$.

The results suggest that the prevalence of Chlamydial infection is relatively large in small ruminants in this region. Veterinarians and people in charge of animal health should adopt an adequate policy of surveillance and prevention in order to control this pathology.
\end{abstract}

Keywords: Chlamydiosis, abortions, sera, indirect ELISA, Chlamydia antibodies, small ruminants.

\section{INTRODUCTION}

Chlamydial infection is one of the pathologies which induce abortion in small ruminants; two species of Chlamydia have been reported to cause infections in sheep, C. abortus and $C$. pecorum (Lenzko et al., 2011). These bacteria have a unique developmental cycle. Members of the genus Chlamydia are gram-negative bacteria and obligate intracellular bacterial parasites responsible for a variety of diseases in humans and animals, including several zoonoses (Pannekoek et al., 2010). The reservoir is large and includes many wild and domestic mammals but domestic ruminants such as sheep, cattle and goat represent the most frequent source of human infection (Berri et al., 2009).

Chlamydial abortion in small ruminants is a zoonotic disease mainly related to Chlamydia abortus. This bacterium is the causative agent of abortion in late pregnancy and foetal loss in sheep, goats and cattle in many countries around the world (Aitken and Longbottom, 2007). In addition, the bacterium has been isolated from cases of epididymitis, pneumonia, arthritis, conjunctivitis, and from the faeces of healthy sheep and goats (Denamur, 1991; Souriau, 1993; Salinas, 1995; Salti-Montesanto, 1997). Infected pregnant ewes and goats abort late in gestation or give birth to weak animals as a result of affected placentas. Bacteria excreted at abortion are the main source of infection of susceptible animals through ingestion or inhalation of the uterine discharge.

Ruminants, in particular, are also infected by $C$. pecorum and commonly isolated from the digestive tract of clinically inconspicuous ruminants; this bacterium was recognized to be a cause of fertility disorders, conjunctivitis, arthritis, 
mastitis, pulmonary inflammation, in sheep, goat and cattle (Fukushi and Hirai, 1992). Chlamydia pecorum strains were isolated from abortion cases of goat and sheep (unpublished data) suggesting that this bacterium might be involved in small ruminants abortion in North African countries (Berri et al., 2009). Stillbirth and infertility, leading to important economic losses, are also associated $t$

In Algeria, abortion cases are frequently reported by veterinarians but, except for brucellosis, which is a notified disease in this country, there is little information on the prevalence and epidemiology of small ruminants abortion causes. The present study aimed to detect Chlamydia antibodies and evaluate the importance of this infection in small ruminants in the region of Ksar El-Boukhari.

\section{MATERIALS AND METHODS}

Description of the study area. The region of Ksar El-Boukhari is a plateau of an area of more than $3288 \mathrm{~km} 2$. It is a transition zone between the mountain range of the Atlas Tellien, in the North, and the high plains of M'sila and Djelfa, in the South. The Northern mountain range rises at an over 1000 meters high altitude. The plateau rises at an altitude of more than 600 meters high; the pluviometry is between 100 and $500 \mathrm{~mm}$ per year. In winter, the temperatures can fall down below - $5^{\circ} \mathrm{c}$, whereas in the summer, they sometimes rise over $42^{\circ} \mathrm{C}$ (Dahmani, 2011). This is a region which contains reproduction herds in the south, practising transhumance all year long, and herds brought up for their meat in the north (Rahal et al., 2011). The livestock of this region records 2200 herds, according to the 2010 vaccination campaign, whereas the average size of the herds in the region is an estimated $(83 \pm 58)$ animals (Dahmani, 2011).

Animal sampling. This study was conducted on 144 blood samples collected from small ruminants (sheep and goats) in 17 herds in the region of Ksar El-Boukhari. Samples were collected from females in randomly selected farms and the proportion of sampled animals was around $10 \%$. This figure was taken from the local elementary surveys conducted in these areas on the number of aborted and normal lambing females. Animals were between 2 to 3 years old. All of them were not vaccinated against abortive chlamydiosis. Blood was drawn from the jugular vein and let decant at room temperature then centrifuged at $1500 \times \mathrm{g}$ for $10 \mathrm{~min}$. Sera were collected and stored at $-20^{\circ} \mathrm{C}$ until further analysis.

Serology. Serum samples were analyzed with a Chlamydiaceae indirect enzyme-linked immunosorbent assay (iELISA) kit " LSI Vet. Ruminant serum Chlamydiosis, Lissieu -France). The assay was performed and results calculated according to the manufacturer's instructions. The iELISA employed does not discriminate between C. abortus and C. pecorum.

\section{RESULTS AND DISCUSSION}

A total of 144 animals were selected for this study, Chlamydia antibodies were detected in 51 animals (35 \pm 08$) \%$. At herd level, 15 farms (88 \pm $15) \%$ were positive, herds with one seropositive animal to ELISA were considered infected. Seroprevalences were highly variable in farms. A rate equal or greater than $50 \%$ was observed in $5 / 17$ farms and 9/17 farms showed a rate equal or greater than $20 \%$ (Tab. 1).

Significant association was observed between flock size and the occurrence of Chlamydia antibodies (Tab. 2). The larger the flock size, the higher the prevalence of chlamydial infection because it increases the probability of infection as it multiplies contacts between animals and the surrounding contaminated sources of infection. Al-Qudah (2004) mentioned that there was a significant association between the two factors.

The first report of the presence of Chlamydia in sheep and goats in Algeria was described by Dumas in the late 70's in the region of Hoggar using complement fixation test (CFT) (Dumas, 1984). Recently, a seroprevalence survey conducted on randomly selected ewes (between 29 and 56 month-old) revealed that $70.4 \%$ of herds and $24.5 \%$ animals had been infected by Chlamydiaceae in the northeast of Algeria (Heriche et al., 2013). In comparison with this study, results of our work indicate higher prevalence rates of chlamydial infection. The seroprevalence rates were very high in both studies. Maybe the female age range (females between 1 and 3 years) being more susceptible to infections (Rekiki et al., 2005), breeding conditions as well as using ELISA test, which targeted antibodies directed against all Chlamydiaceae, could explain the high rates.

Results of the present survey revealed a seroprevalence in flocks of ( $88 \pm 15) \%$ which was 
higher than that reported by studies conducted in Maghreb countries and which showed variable seroprevalence rates. Indeed, a Tunisian survey revealed that $24.5 \%$ and $60 \%$ of flocks were tested positive (Rekiki et al., 2005). A rate of $28,6 \%$ was revealed in a Moroccan survey (El Jai S. et al., 2003). However, a comparison between all these surveys would be cumbersome due to numerous parameters such as differences in study design, flock size and management, the variety of applied techniques (CFT, ELISA), which lead us to caution. However, the climatic conditions and breeding practices are similar in these countries and the animal trading in borders is common, the sanitary situation of the breeding herds in these countries is expected to be the same.
This study concluded that $(88 \pm 15) \%$ of herds had at least one seropositive animal. The high herd prevalence estimated herein indicated a widespread infection in the region.

Veterinarians and responsible of animal health should expand their investigations and find solutions to control chlamydial infections in small ruminants.

\section{CONCLUSION}

This study allowed us to detect the presence of Chlamydia antibodies induced by natural infection. The findings confirmed that pathogens are circulating in farms, and had been demonstrated by iELISA. The assay used in the present study, which specifically detects antibodies to both $C$. abortus

Tab.1. Distribution of seropositive cases in the 17 farms.

\begin{tabular}{ccccc}
\hline Farms & Animal number & $\begin{array}{c}\text { Animal number } \\
\text { tested }\end{array}$ & $\begin{array}{c}\text { Seropositive } \\
\text { number }\end{array}$ & Seropositives (\%) \\
\hline A & 103 & 10 & 5 & 50 \\
\hline B & 118 & 10 & 6 & 60 \\
\hline C & 58 & 5 & 4 & 80 \\
\hline D & 130 & 12 & 4 & 33,3 \\
\hline E & 45 & 4 & 1 & 0 \\
\hline F & 38 & 3 & 0 & 55,6 \\
\hline G & 85 & 9 & 5 & 0 \\
\hline H & 40 & 4 & 0 & 53,9 \\
\hline I & 38 & 4 & 1 & 31,25 \\
\hline J & 152 & 13 & 7 & 20 \\
\hline K & 172 & 16 & 5 & 16,7 \\
\hline L & 110 & 10 & 2 & 20 \\
\hline M & 60 & 6 & 1 & 30 \\
\hline N & 105 & 10 & 2 & 20 \\
\hline O & 100 & 10 & 3 & 35.41 \\
\hline P & 82 & 8 & 3 & \\
\hline Q & 95 & 10 & 2 & 51 \\
\hline Total & - & 144 & & \\
\hline & & & 51 & \\
\hline
\end{tabular}

Tab. 2 Percentage of seropositive cases according to flock size

\begin{tabular}{cccc}
\hline Flock size & $\begin{array}{c}\text { Number of } \\
\text { farms tested }\end{array}$ & $\begin{array}{c}\text { Number } \\
\text { tested }\end{array}$ & Seropositives (\%) \\
\hline$<50$ & 4 & 15 & $2(13.3)$ \\
\hline 50 à 100 & 5 & 38 & $15(39.4)$ \\
\hline 100 à 150 & 6 & 52 & $20(38.4)$ \\
\hline$>150$ & 2 & 39 & $14(35.8)$ \\
\hline
\end{tabular}


and C. pecorum, found a high seroprevalence in small ruminants in this region, suggesting these bacteria have an important role in causing reproductive disease . Furthermore, the presence of Chlamydia species in farms may represent a threat to human and animal health; the prevention measures should be adopted to control these risks.

We recommend further investigations to demonstrate the impact of Chlamydial infections on sheep and goats in Algeria.

Acknowledgements. The study was supported by the University of Blida, Algeria. We are grateful to the team of Chlamydia from Maisons-Alfort Laboratory for Animal Health -ANSES France- for their excellent technical assistance. Special thanks to $\mathrm{C}$. Laroche for her precious help for reviewing the manuscript.

\section{REFERENCES}

1. Aitken ID, Longbottom D (2007). Chlamydial abortion, p. 105-112. In: Aitken, I.D. (Eds.). Diseases of Sheep. Blackwelll Publishing, Oxford, UK.

2. Al-Qudah KM, Sharif LA, Raouf RY, Hailat NQ Al-Domy FM (2004). Seroprevalence of antibodies to Chlamydophila abortus shown in awassi sheep and local goats in Jordan, Veterinarni Medicina 49:460-466.

3. Berri M, Rekiki A, Sidi Boumedine K, Rodolakis A. (2009) Simultaneous differential detection of Chlamydophila abortus, Chlamydophila pecorum and Coxiella burnetii from aborted ruminant's clinical samples using multiplex PCR. BMC Microbiology 9, 130.

4. Dahmani A (2011). Dystocia in sheep in the region of Ksar El-Boukhari, Institute of veterinary science of Blida, Algeria, PhD Diss. 65-72.

5. Denamur E, Sayada C, Souriau A, Orfila J, Rodolakis A, Elion J (1991). Restriction pattern of the major outer-membrane protein gene provides evidence for a homogeneous invasive group among ruminant isolates of Chlamydia psittaci. J. Genet. Microbiol. 137: 2525-2530.

6. Dumas N (1984). Rickettsiosis and chlamydiosis in Hoggar (Republic of Algeria): Epidemiological sampling, Bull. Soc. Pathol. Exot. Filiales 77:278-83.
7. El Jai S, Bouslikhane M, El Idrissi AH, (2003). Suivi épidémiologique des avortements de petits ruminants dans les zones pastorales du Maroc. Actes Inst. Agron. Vet. Maroc, 23:95-100.

8. Fukushi H, Hirai, K (1992). Proposal of Chlamydia pecorum sp. nov. for Chlamydia strains derived from ruminants. Int. J. Syst. Bacteriol. 42:306-308.

9. Hireche S, Bouaziz O, Djenna D. Boussena S, Aimeur R, Kabouia R, Bererhi E (2014). Seroprevalence and risk factors associated with Chlamydophila spp. infection in ewes in the northeast of Algeria. Trop. Anim. Health. Prod.46: 467-473.

10. Lenzko $H$, Moog U, Henning $K$, Lederbach R, Diller R, Menge C, Sachse K, Sprague L D, (2011). High frequency of chlamydial co-infections in clinically healthy sheep flocks. BMC Veterinary Research 7:29.

11. PannekoekY, Morelli G, Kusecek B, MorréSA, Ossewaarde JM, Langerak AA, Van der Ende A (2008). Multi locus sequence typing of Chlamydiales: clonal groupings within the obligate intracellular bacteria Chlamydia trachomatis. BMC Microbiol. 8:42-52.

12. Rahal K, Bennadji A, Dahmani A, Dechicha A, Khaled H, Merdja S, Lounes N, Rousset E, Sidi Boumedine K. Thiery R, Laroucau K, Garin-Bastuji B, Bouyoucef A (2011). Séroprévalence apparente de la brucellose, chlamydiose et fièvre $Q$ chez les ovins de la région de Ksar Boukhari. Proc. 4èmes journées vétérinaires de Blida, Algérie. 13-16.

13. Rekiki A, Thabti F, Dlissi I, Russo P, Sanchis R, Pepin M, Hammami A (2005). Enquête sérologique sur les principales causes d'avortements infectieux chez les petits ruminants en Tunisie. Revue Méd. Vét. 156 :395-401

14. Salinas, J., Souriau, A., Cuello, F., Rodolakis, A., (1995). Antigenic diversity of ruminant Chlamydia psittaci strains demonstrated by the indirect micro-immunofluorescence test with monoclonal antibodies. Vet. Microbiol. 43, 219226.

15. Salti-Montesanto V, Tsoli E, Papavassiliou P, Psarrou E, Markey BK, Jones GE, Vretou E, (1997). Diagnosis of ovine enzootic abortion, using a competitive ELISA based on monoclonal antibodies against variable segments 1 and 2 of the major outer membrane protein of Chlamydia psittaci serotype1. Am. J. Vet. Res. 58 :228-235.

16. Souriau A, Le Rouzic E, Bernard F, Rodolakis A (1993). Differentiation of abortion-inducing and intestinal strains of Chlamydia psittaci isolated from ruminants by the microimmunofluorescence test. Vet. Rec. 132: 217-219. 